\title{
Comparative Evaluation of the Efficacy of Indirect Hemagglutination Test and Radiological Methods in the Pre-diagnosis of Cystic Echinococcosis
}

\author{
IHA ve Radyolojik Yöntemlerin Kistik Ekinokokkoz Ön Tanısindaki \\ Etkinliklerinin Karşılaştırmalı Olarak Değerlendirilmesi
}

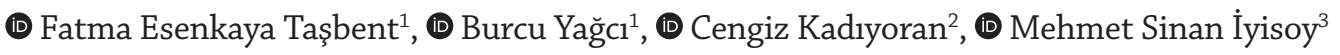 \\ ${ }^{1}$ Necmettin Erbakan Üniversitesi Meram Tip Fakültesi, Tibbi Mikrobiyoloji Anabilim Dall, Konya, Türkiye \\ ${ }^{2}$ Necmettin Erbakan Üniversitesi Meram Tıp Fakültesi, Radyoloji Anabilim Dalı, Konya, Türkiye \\ ${ }^{3}$ Necmettin Erbakan Üniversitesi Meram Tıp Fakültesi, Tıp Eğitimi ve Bilişimi Anabilim Dalı, Konya, Türkiye
}

Cite this article as: Esenkaya Taşbent F, Yağcı B, Kadıyoran C, İyisoy MS. Comparative Evaluation of the Efficacy of

Indirect Hemagglutination Test and Radiological Methods in the Pre-diagnosis of Cystic Echinococcosis.

Turkiye Parazitol Derg 2021;45(1):22-27

\section{öz}

Amaç: Kistik ekinokokkoz (KE) ülkemizde yaygın görülen bir halk sağlığı problemidir. Bu çalışmada bir üniversite hastanesinde geriye dönük beş yıllık dönemde, KE şüphesiyle istenilen radyolojik görüntüleme yöntemleri ile serolojik test sonuçları arasındaki uyumun araştırılması ve yaşadığımız bölgedeki KE sıklığının değerlendirilmesi amaçlanmıştır.

Yöntemler: Çalışmada Ocak 2014 ile Aralık 2018 tarihleri arasında KE şüphesi ile çeşitli kliniklerden gönderilen 1,046 hastanın indirekt hemaglütinasyon test (IHA) sonuçları retrospektif olarak incelenmiştir. İncelenen 1,046 hastadan sistemde kayıtlı en az bir radyolojik görüntüleme raporu olduğu tespit edilen 938'i bu çalışmaya dahil edilmiştir. Radyolojik görüntüleme bulguları ve IHA test sonuçları irdelenmiştir.

Bulgular: Çalışmaya alınan 938 hastanın 143'ünde (\%15,2) IHA testi ile seropozitiflik saptanmıştır. IHA testi pozitif bulunan 143 hastanın 130'unda $(\% 90,9)$ en az bir radyolojik görüntüleme raporunda KE bulgusu olduğu kaydedilmiştir. Tüm hastaların ise 362 'sinde $(\% 38,5)$ radyolojik görüntüleme raporlarından en az birinde KE bulgusu görülmüştür.

Sonuç: Çalışmada KE tanısında serolojik test ve radyolojik görüntüleme yöntemlerinin birlikte kullanılması gerektiği sonucuna varılmıștır.

Anahtar Kelimeler: Kistik ekinokokkoz, Echinococcus granulosus, IHA

\section{ABSTRACT}

Objective: Cystic echinococcosis (CE) is a common public health concern in Turkey. In this study, we investigated the agreement between the results of radiological imaging methods and serological tests through a 5-year retrospective evaluation in patients admitted to a university hospital with a suspicion of $\mathrm{CE}$ so as to determine the frequency of $\mathrm{CE}$ in the study region.

Methods: The indirect hemagglutination test (IHA) results of 1.046 patients obtained from various clinics with the suspicion of CE between January 2014 and December 2018 were retrospectively analysed. Of these, patients with at least one radiological imaging report in the system (938 patients) were included in the study. Radiological imaging findings and IHA test results were compared and examined.

Results: Seropositivity was detected by IHA test in 143 (15.2\%) of 938 patients included in the study. The CE findings were recorded in at least one radiological imaging report in 130 (90.9\%) of 143 patients with positive IHA test. At least one of the radiological imaging reports suggested presence of CE in 362 (38.5\%) of all the patients.

Conclusion: Thus, serological test and radiological imaging methods should be used in combination for the diagnosis of $C E$. Keywords: Cystic echinococcosis, Echinococcus granulosus, IHA 


\section{GIiRiş}

Kistik ekinokokkoz (KE) Echinococcus granulosus'nin (E. granulosus) neden olduğu, insan sağllğını tehdit eden zoonotik bir paraziter enfeksiyondur (1). Son konak köpek ve köpekgiller tarafından dış ortama atılan parazit yumurtalarının, insan ve doğal ara konaklar olan koyun, keçi, sığır tarafından sindirim veya solunum yolu ile alınmasıyla enfeksiyon gelişebilmektedir (2). Ara konak tarafindan alınan E. granulosus yumurtalarından gelişen larval form, iç organlarda kistik lezyonlar oluşturmaktadır (3). Parazit başta karaciğer olmak üzere; akciğer, böbrek, dalak, beyin, kemik, kalp gibi hemen her organa yerleşebilmekte ayrıca her yaştan bireyi etkileyebilmektedir. KE genellikle asemptomatik seyirli iken şiddetli lokal yada sistemik semptomlar da gösterebilmektedir $(4,5)$. Parazitozun sebep olduğu klinik belirti ve bulgular; kistin yerleşim gösterdiği bölgeye, boyutuna, gelişimsel evresine, çevre doku ve yapılar üzerindeki bası yapma durumuna ve enfekte olmuş kişinin savunma mekanizmasına bağlıdır. Bunun yanı sıra KE; kesin tanı koymak için yapılan detaylı tetkikler, hastanede yatış süresi, uygulanan medikal/cerrahi tedaviler ve tüm bunlara bağlı iş gücü kaybı düşünüldüğünde önemli bir sağlık sorunudur (6).

Parazitozun tanısında genellikle radyolojik görüntüleme yöntemlerinden ve serolojik testlerden yararlanılmaktadır. Radyolojik tetkikler ile kistin görüntülenmesi günümüzde en çok başvurulan tanı yöntemlerindendir. Birçok asemptomatik kist hidatik hastası başka bir nedenle yapılan radyolojik tetkikler ile saptanmaktadır. Farklı radyolojik görüntüleme yöntemlerinden yararlanılabilinirken, kistin lokalizasyonuna göre tercih edilen yöntem değişebilmektedir. Karaciğer kist hidatiğinde ultrasonografi (USG) çok değerli iken akciğer kistlerinde genellikle direkt grafi ilk tercih olarak kullanılmaktadır. Bilgisayarlı tomografi (BT) ve manyetik rezonans görüntüleme ise hemen hemen tüm organ yerleşimlerinde kullanılabilir (7).

Serolojik testler ise özellikle görüntüleme yöntemleri ile saptanan yer kaplayıcı diğer lezyonların ayırıcı tanısının yapılabilmesi ve ameliyat sonrası hasta takibinde önem taşımaktadır (8). İndirekt hemaglütinasyon testi (IHA), ELİSA, Western Blot ve İndirekt Floresan Antikor testi KE tanısında yaygın bir şekilde kullanılan serolojik yöntemlerdir (9). Hastanın serumunda özgül anti-E. granulosus antikorlarının arandığı IHA; uygulaması kolay, kısa sürede sonuç alınan ve güvenilir bir yöntem olması sebebiyle sık tercih edilmektedir (6).

IHA testi ilk kez 1957 yılında Garabedian ve ark. (10) tarafından 16 hastada kullanılmış olup, hastaların 13'ünde (\%81) pozitiflik tespit edilmiştir. Ancak bu testte ekinokok türü ile ortak antijen taşımaları nedeniyle; Taenia solium, Taenia saginata, Ascaris lumbricoides, Fasciola hepatica, Toxoplasma gondii ve Plasmodium enfeksiyonlarında da yanlış pozitiflik görülebilmektedir. Bu çapraz reaksiyonlar nedeniyle, düşük titrelerde yanlış pozitiflik riski yüksek olduğundan, kist hidatik tanısı için IHA'da 1/360 ve üzerindeki titreler anlamlı kabul edilmektedir (11).

Bu çalışmada 2014-2018 yıllarını kapsayan beş yıllık dönemde, KE'den şüphelenilerek istenilen radyolojik görüntüleme yöntemleri ile serolojik test sonuçları arasındaki uyumun ve yaşadığımız bölgedeki KE sıklığının değerlendirilmesi amaçlanmıştır.

\section{YÖNTEMLER}

Çalışmada Ocak 2014-Aralık 2018 tarihleri arasında bir üniversite hastanesi parazitoloji laboratuvarına KE ön tanısı ile çeşitli kliniklerden gönderilen 1,046 hastanın, yapılan IHA test sonuçlarının yanı sıra yaş, cinsiyet ve radyolojik bulguları hastane otomasyon sisteminde kayıtlı veriler üzerinden değerlendirilmiştir. $\mathrm{Bu}$ çalışma için Necmettin Erbakan Üniversitesi Etik Kurulu'ndan izin alınmıştır (2019/98). Veri analizinde 1,046 hastanın 938'inin sistemde kayıtlı en az bir radyolojik görüntüleme raporu (USG, BT ve/veya MR) olduğu tespit edilerek bu hastalar çalışmaya dahil edilmiştir. En az bir radyolojik görüntüleme raporunda $\mathrm{KE}$ bulgusu mevcut olan hastalarda kistin lokalizasyonu kaydedilmiştir.

Laboratuvar çalışmasında, IHA yöntemi serum örneklerinden, ticari kit (Hydatidose, Fumouze Laboratoires, France) ile test prosedürüne uygun olarak çalışılmıştır. Serum sulandırımları U tabanlı mikroplaklarda yapılmıştır. Antijenli eritrosit süspansiyonu eklenmiş serum dilüsyonlarında, 2 saatlik inkübasyon sonrası düğme iliği şeklinde çökelti varsa sonuç negatif, kenarı düzensiz bir çökelti olması veya çökelti olmaması pozitif olarak değerlendirilmiştir. Bu hastalardan, test sonucu elde edilen titrasyon değeri $1 / 320$ ve üzeri bulunanlar pozitif olarak kaydedilmiştir. Çalışılan ticari kitin duyarlılığı \%93, özgüllüğü \%94,9 olarak belirtilmektedir.

\section{İstatistiksel Analiz}

Çalışmanın istatistiksel analizinde değişkenler için tanımlayıcı istatistikler verilmiştir. Sayısal değişkenler ortalama (standart sapma) şeklinde, kategorik değişkenler frekans (yüzde) şeklinde ifade edilmiştir. Kategorik değişkenler için yapılan analizlerde chi-square and Cochran Armitage testleri uygulanmıştır. IHA ve radyoloji verileri arasındaki uyumu araştırmak icin Cohen's kappa istatistiği kullanılmıştır. Analizler SAS University Edition 9.4 programı ile yapılarak, $\mathrm{p}<0,05$ değeri anlamlı kabul edilmiştir.

\section{BULGULAR}

Çalışmaya yaş ortalaması 44,51 (22,27) olan 503 kadın $(\% 53,6)$, $435(\% 46,3)$ erkek olmak üzere toplam 938 hasta dahil edilmiştir. Hastaların yaş dağılımları incelendiğinde 183'ünün (\%19,51) 0-18 yaş, 173'ünün $(\% 18,44)$ 19-40 yaş, 406'sının $(\% 43,28)$ 41-65 yaş ve 176 'sının da $(\% 18,76) 66$ yaş ve üzerinde olduğu görülmüştür (Şekil 1).

Hastaların IHA ve radyoloji sonuçları Tablo 1'de özetlenmiştir. Tüm hastaların 143'ünde (\%15,2) IHA testi ile seropozitiflik saptanırken, geri kalan $795(\% 84,7)$ hastanın serumunda antikor belirlenememiştir. Seropozitif 143 hastanın 77'si (\%53,8) kadın, 66'sı $(\% 46,2)$ erkektir. En yüksek seropozitivite oranına sahip yaş aralığı ise $54(\% 37,7)$ hastayla $41-65$ yaş aralığı olarak saptanmıştır. Ancak IHA testi pozitifliğinin yaşa göre $(p=0,52)$ ve cinsiyete göre $(p=0,95)$ değişmediği gösterilmiştir. Tüm hastaların 362'sinde $(\% 38,5)$ USG, BT ve MR raporlarından en az birinde KE düşündüren bulgular izlendiği raporlanmıştır (Tablo 1). Radyolojik bulguların ve IHA test sonuçlarının yıllara göre değişimi Tablo 2'de gösterilmiştir.

IHA ile radyolojik görüntüleme yöntemleri arasındaki uyum analizi için Cohen kappa değeri hesaplanmış ve $\kappa=0,38(0,32-$ $0,43)$ olarak bulunmuştur. Bu uyum düşük-orta düzey olarak yorumlanmıştır. IHA ve radyolojik yöntem arasındaki uyum 
düzeyleri Şekil 2'de gösterilmiştir. Yöntemler arasındaki uyum cinsiyete göre araştırıldığında $\kappa$-değeri erkeklerde $0,39(0,31$ 0,48), kadınlarda $0,37(0,30-0,44)$ olarak bulunmuştur. Yaş gruplarında ise 0-18 yaşlarda 0,42 (0,29-0,54), 19-40 yaşlarda $0,35(0,22-0,48), 41-65$ için $0,37(0,29-0,45)$ ve 65 yaş üzeri için $0,39(0,27-0,51)$ olarak hesaplanmıştır.

Seropozitif hastaların titrelere göre dağılımı Tablo 3'te görülmektedir. Hastalardan 78'inde $(\% 8,3)$ düşük titrasyon değerleri görülmüş ancak bu hastalar 1/320 titrasyonun altında oldukları için negatif olarak kaydedilmiştir. IHA titre seviyeleri ile radyoloji pozitifliği arasındaki uyum Cochran Armitage yesti ile araştırıldığında anlamlı bir ilişki bulunmuştur $(p<0,001)$. Negatiften, 1/5,120'ye kadar titre değerleri ile radyolojik görüntüleme pozitifliği karşılaştırıldığında, yüksek titre değerlerinde radyolojik görüntüleme pozitifliğinin daha fazla olduğu görülmektedir (Tablo 3).

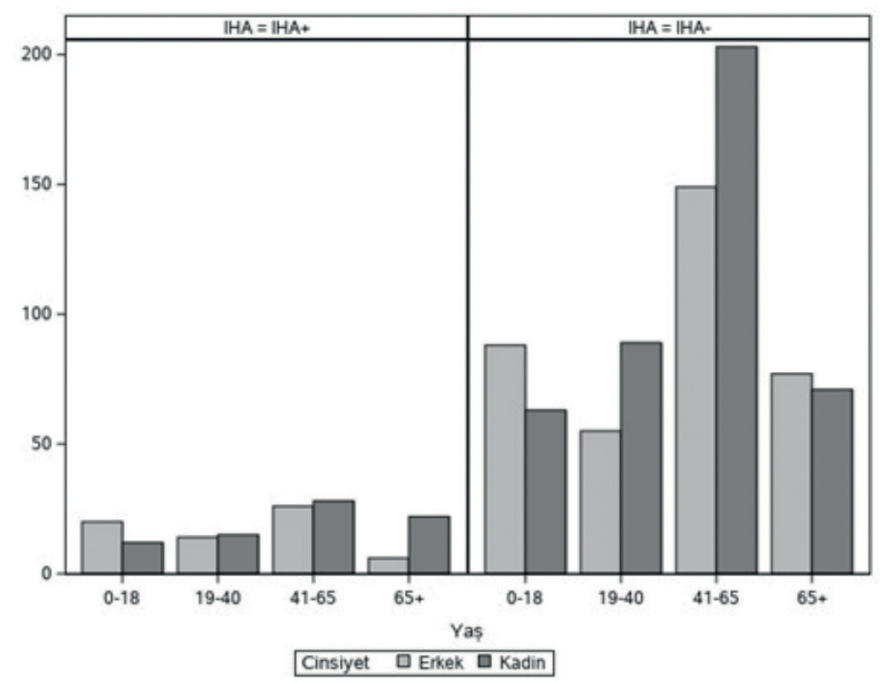

Şekil 1. IHA pozitif hastaların yaş ve cinsiyet gruplarına göre dağılımı

IHA: İndirekt hemaglütinasyon test

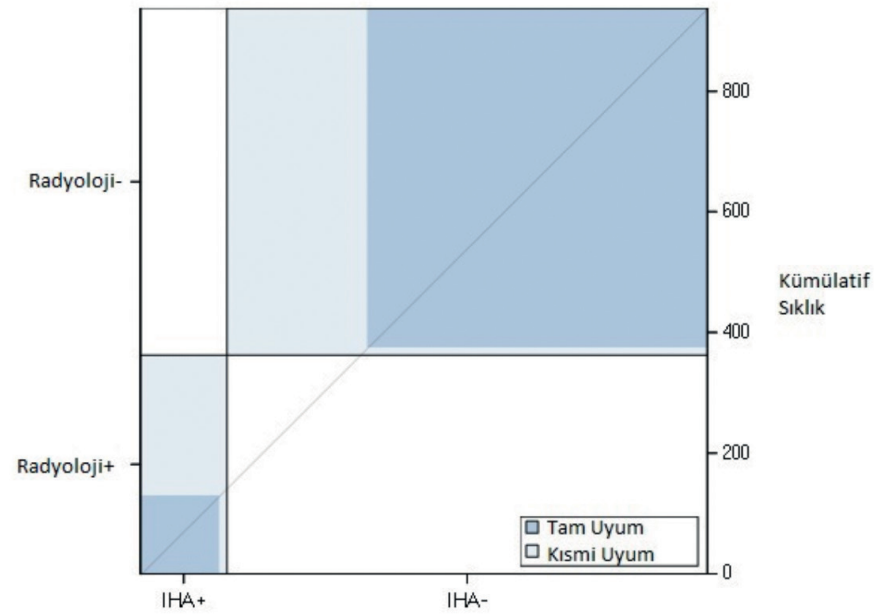

Şekil 2. IHA ve radyolojik yöntem arasındaki uyum durumu IHA: Indirekt hemaglütinasyon test
Radyolojik görüntüleme yöntemleri ile saptanan kistin lokalizasyonlarının dağılımı ve IHA pozitiflik oranları Tablo 4'te görülmektedir. Radyolojik olarak kist hidatik bulgusu saptanan hastalarda en yüksek organ tutulumu $311(\% 85,9)$ hasta ile karaciğerde izlenmiştir. Radyoloji bulgusu pozitif olan hastalarda IHA pozitifliğini kist lokalizasyonuna göre değerlendirdiğimizde radyolojik karaciğer kist hidatiği düşünülen hastalarda IHA pozitiflik oranı \%37,62 iken diğer organ lokalizasyonlarında bu oran \%25,49 olarak bulunmuştur. Ancak kistin lokalizasyonu ile IHA pozitifliği arasında anlamlı bir ilişki bulunamamıştır $(\mathrm{p}=0,09)$.

\section{TARTIŞMA}

KE halen tüm dünyada halk sağlığını tehdit eden önemli bir zoonotik paraziter enfeksiyondur. Ülkemizde de zoocoğrafik farklılıklar, iklim koşulları, toplumda hastalıkla ve bulaşma yolları ile ilgili eğitim eksikliği gibi nedenlerle KE geniş bir yayılım göstermektedir $(8,12)$. Türkiye'deki KE prevalansının 100.000'de 50 , insidansının ise 100.000 'de 2 civarında olduğu belirtilmektedir (13). Ülkemizin tüm bölgelerine ait kistik ekinokokkozis verilerini içeren çok merkezli geriye dönük bir araştırmada; 20012005 yılları arasında ülkemizdeki seroprevalansının coğrafik bölgelere bağlı farklılık göstermekle birlikte \%2,75 ile \%38,57 arasında değiştiği bildirilmektedir (14). Bu çalışmada incelenen

Tablo 1. Hastaların IHA ve radyoloji sonuçları

\begin{tabular}{|l|l|l|l|}
\hline & $\begin{array}{l}\text { Radyolojik bulgu } \\
\text { pozitiflik sayısı } \\
(\mathbf{\%})\end{array}$ & $\begin{array}{l}\text { Radyolojik bulgu } \\
\text { negatiflik sayısı } \\
(\mathbf{\%})\end{array}$ & Toplam \\
\hline IHA pozitif & $130(\% 90,9)$ & $13(\% 9,1)$ & 143 \\
\hline IHA negatif & $232(\% 29,2)$ & $563(\% 70,8)$ & 795 \\
\hline Toplam & 362 & 576 & 938 \\
\hline IHA: İndirekt hemaglütinasyon test \\
\hline
\end{tabular}

Tablo 2. Radyolojik bulguların ve IHA test sonuçlarının yıllara göre değişimi

\begin{tabular}{|c|c|c|c|c|}
\hline Yillar & $\begin{array}{l}\text { IHA } \\
\text { sonucu }\end{array}$ & $\begin{array}{l}\text { Radyoloji } \\
\text { (+) sayısi }\end{array}$ & $\begin{array}{l}\text { Radyoloji } \\
\text { (-) sayısi }\end{array}$ & Toplam \\
\hline \multirow{3}{*}{2014} & IHA (+) & 25 & 2 & 27 \\
\hline & IHA (-) & 50 & 114 & 164 \\
\hline & Toplam & 75 & 116 & 191 \\
\hline \multirow{3}{*}{2015} & IHA (+) & 21 & 3 & 24 \\
\hline & IHA (-) & 56 & 141 & 197 \\
\hline & Toplam & 77 & 144 & 221 \\
\hline \multirow{3}{*}{2016} & $\operatorname{IHA}(+)$ & 39 & 4 & 43 \\
\hline & IHA (-) & 36 & 104 & 140 \\
\hline & Toplam & 75 & 108 & 183 \\
\hline \multirow{3}{*}{2017} & $\operatorname{IHA}(+)$ & 20 & 1 & 21 \\
\hline & IHA (-) & 33 & 68 & 101 \\
\hline & Toplam & 53 & 69 & 122 \\
\hline \multirow{3}{*}{2018} & $\operatorname{IHA}(+)$ & 26 & 2 & 28 \\
\hline & IHA (-) & 56 & 137 & 193 \\
\hline & Toplam & 82 & 139 & 221 \\
\hline
\end{tabular}


Tablo 3. IHA titreleri ve radyolojik görüntülemede KE pozitifliği

\begin{tabular}{|c|c|c|c|c|c|c|c|c|c|}
\hline IHA titreleri & 0 & $1 / 40$ & $1 / 80$ & $1 / 160$ & $1 / 320$ & $1 / 640$ & $1 / 1,280$ & $1 / 2,560$ & $1 / 5,120$ \\
\hline $\begin{array}{l}\text { Radyoloji (+) } \\
\text { sayısı (\%) }\end{array}$ & $\begin{array}{l}185 \\
(\% 25,8)\end{array}$ & $\begin{array}{l}7 \\
(\% 36,8)\end{array}$ & $\begin{array}{l}3 \\
(\% 37,5)\end{array}$ & $\begin{array}{l}37 \\
(\% 72,5)\end{array}$ & $\begin{array}{l}23 \\
(\% 82,1)\end{array}$ & $\begin{array}{l}20 \\
(\% 90,9)\end{array}$ & $\begin{array}{l}69 \\
(\% 92)\end{array}$ & $\begin{array}{l}13 \\
(\% 100)\end{array}$ & $\begin{array}{l}5 \\
(\% 100)\end{array}$ \\
\hline $\begin{array}{l}\text { Radyoloji (-) } \\
\text { sayısı (\%) }\end{array}$ & $\begin{array}{l}532 \\
(\% 74,2)\end{array}$ & $\begin{array}{l}12 \\
(\% 63,2)\end{array}$ & $\begin{array}{l}5 \\
(\% 62,5)\end{array}$ & $\begin{array}{l}14 \\
(\% 27,4)\end{array}$ & $\begin{array}{l}5 \\
(\% 17,8) \\
\end{array}$ & $\begin{array}{l}2 \\
(\% 9,1)\end{array}$ & $\begin{array}{l}6 \\
(\% 8)\end{array}$ & $\begin{array}{l}0 \\
(\% 0)\end{array}$ & $\begin{array}{l}0 \\
(\% 0)\end{array}$ \\
\hline Toplam & $\begin{array}{l}717 \\
(\% 100)\end{array}$ & $\begin{array}{l}19 \\
(\% 100)\end{array}$ & $\begin{array}{l}8 \\
(\% 100)\end{array}$ & $\begin{array}{l}51 \\
(\% 100)\end{array}$ & $\begin{array}{l}28 \\
(\% 100)\end{array}$ & $\begin{array}{l}22 \\
(\% 100)\end{array}$ & $\begin{array}{l}75 \\
(\% 100)\end{array}$ & $\begin{array}{l}13 \\
(\% 100)\end{array}$ & $\begin{array}{l}5 \\
(\% 100)\end{array}$ \\
\hline
\end{tabular}

\begin{tabular}{|c|c|c|c|}
\hline $\begin{array}{l}\text { Kistik ekinokokkoz } \\
\text { lokalizasyonu }\end{array}$ & IHA (+) & IHA (-) & Toplam \\
\hline Karaciğer & 117 & 194 & $311(\% 85,9)$ \\
\hline Akciğer & 4 & 19 & $23(\% 6,3)$ \\
\hline Akciğer + karaciğer & 5 & 6 & $11(\% 3)$ \\
\hline Böbrek & 3 & 4 & $7(\% 1,9)$ \\
\hline Böbrek + karaciğer & - & 1 & $1(\% 0,3)$ \\
\hline Dalak & - & 3 & $3(\% 0,8)$ \\
\hline Dalak + karaciğer & - & 2 & $2(\% 0,5)$ \\
\hline Pankreas & - & 2 & $2(\% 0,5)$ \\
\hline Pankreas + karaciğer & 1 & - & $1(\% 0,3)$ \\
\hline Kalp & - & 1 & $1(\% 0,3)$ \\
\hline Toplam & 131 & 231 & $362(\% 100)$ \\
\hline
\end{tabular}

çalışma mevcuttur. Ülkemizde Güreser ve ark.'nın (16) 253 hasta içeren çalışmasında IHA testi pozitif bulunan 32 hastanın tamamında radyolojik bulgular pozitif olarak bildirilmiştir. Aynı çalışmada seronegatif iki hastada radyolojik olarak KE bulguları kaydedilmiştir (16). Almanya merkezli bir çalışmada ise IHA testi pozitif bulunan 18 hastanın 14'ünde $(\% 77,8)$ USG yöntemi ile KE düşündüren bulgular izlenmiştir. Yine aynı çalışmada radyolojik bulgusu olan 9 hastada ise IHA testi negatif sonuç vermiştir (17). Çalışmamızda IHA ile radyolojik görüntüleme yöntemlerinin pozitifliği arasındaki uyumu bulmak için Cohen kappa değeri hesaplanmış ve uyum düşük-orta düzey olarak yorumlanmıştır. Dosya taraması ile elde edilen radyolojik verilerin bir kısmının, ön tanı olarak düşünülüp raporlanan veriler olabileceği, bu hastaların uzun dönem takiplerinin yapılmasının önemli olduğu düşünülmektedir. Ayrıca KE tanı yaklaşımında serolojik testler ve ilk adım görüntüleme yöntemlerinin yorumlanmasinın yanı sıra hastanın semptom gösterme durumuna bağlı olarak ileri incelemelere de gereksinim duyulabilmektedir (18). Bu durum hem bu çalışmanın kısıtlılığı hem de iki yöntem arasındaki düşük orta düzey uyumun gerekçesi olarak yorumlanmıştır.

saptanmıştır. Bu oran hayvancilığın yaygın olduğu İç Anadolu Bölgesi'nde yer alan ilimizde parazitozun sıklığı ile ilgili fikir verici olmakla birlikte hastalığın yayılımının ciddiyeti hakkında düşündürücüdür.

KE görülme sıklığının kadınlarda erkeklere göre daha yüksek olduğunu bildiren yayınlar bulunmaktadır $(1,4,6,12,14)$. Bunun yanında KE'yi kadın ve erkeklerde eşit oranlarda gösteren çalışmalar da vardır (15). Çalışmamızda seropozitif 143 hastanın 77’si $(\% 53,8)$ kadın, 66'sı $(\% 46,2)$ erkek olarak bulunmuş; ancak bu fark istatistiksel olarak anlamlı bulunmamıştır. Çalışmalar arası bu farklılığın kimi bölgelerde kadınların kırsal alanda daha çok çalışmasından ve hayvanlarla daha fazla uğraşmasından kaynaklanabileceği düşünülmektedir.

Çalışmamızda en yüksek seropozitivite oranına sahip yaş aralığı $54(\% 37,7)$ hastayla 41-65 yaş aralığı olarak saptanmıştır. Çeşitli çalışmalarda bu yaş aralığının \%31 ile 31-50 yaş aralığı, $\% 75$ ile 40 yaş üzeri, \%40 ile 40-60 yaş aralığı, \%24 oran ile 21-30 yaş aralığında olduğuna dair çalışmalar mevcuttur (1518). Bu yaş dağılımının hastalığın yavaş seyirli bir enfeksiyon olması nedeniyle çocukluk çağında alınan parazitin ileri yaşlarda bulgu vermesinden, kişisel bağışıklık ve bölgesel farklılıklardan kaynaklanmış olabileceği düşünülmektedir.

Çalışmada IHA testi yapılan hastaların geriye dönük olarak radyolojik görüntüleme sonuçları da incelenmiştir. IHA testi pozitif bulunan 143 hastanın 130'unda (\%90,9) en az bir radyolojik görüntüleme raporunda $\mathrm{KE}$ bulgusu kaydedilmiştir. IHA testi negatif bulunan 795 hastanin ise 232'sinde (\%29,1) radyolojik kist hidatik raporlanmıştır. Literatürde KE olgularında seroloji ve radyoloji sonuçlarının birlikte irdelendiği az sayıda

Çalışmada radyoloji bulgusu olan hastaların IHA titrasyon değerleri ile ilişkisi incelenmiştir. IHA testinde titrasyon saptanmayan 717 hastanın \%25,8'inde radyolojik bulgu gözlenmesine karşın, 1/5,120 oranında titrasyon görülen 5 hastanın tamamında (\%100) radyolojik bulguya rastlanmıştır. Bu ikili arasındaki ilişki Cochran Armitage testi ile araştırıldığında anlamlı bulunmuştur $(p<0,001)$ ve titrasyon değeri arttıkça iki yöntem arasındaki uyumun arttığı sonucuna varılmıştır. Ayrıca IHA ile negatif kabul ettiğimiz düşük titrasyon değerlerindeki hastalarda (1/40, 1/80, 1/160), düşük oranlarda da olsa radyolojik pozitiflik saptanmıştır. Hasta takibinde bu düşük titrasyon saptanan hastaların IHA testlerinin tekrarlanmasının anlamlı olabileceği düşünülmüştür. KE en sık karaciğere yerleşmektedir (19). Bu çalışmada da radyolojik olarak KE bulgusu saptanan hastalarda en yüksek oranda organ tutulumu $311(\% 85,9)$ hasta ile karaciğer olmuştur. KE'de en sık karaciğer tutulumunun görülme nedeni, bağırsaktaki portal dolaşımın ilk olarak karaciğere uğramasıdır. Ağızdan alınan E. granulosus yumurtalarından açı̆ga çıkan onkosfer, bağırsak mukozasını aşarak buradaki portal ven yoluyla ilk olarak karaciğere gelir. Bu aşamada karaciğerde yerleşemeyen onkosferler ise akciğerlere ve çok az bir kısmı da sistemik dolaşım ile dalak, böbrek, beyin, kemik, kas gibi organlara ulaşarak buralarda kistik yapılara dönüşürler (20). Çalışmamızda karaciğeri \%6,35 sıklıkla akciğer ve \%1,9 sıklıkla böbrek tutulumları izlemiştir. Miman ve ark. (21) çalışmalarında \%53,85 karaciğer tutulumuna rastlarken bunu \%19,78 ile akciğer tutulumu izlemiştir. Ertabaklar ve ark. (12) 12 ylllık retrospektif veri içeren çalışmalarında karaciğer tutulum oranını \%81,8 ve akciğer tutulumunu \%6,1 oranında 
bulmuşlardır. Yapılan farklı iki çalışmada ise \%46 ila \%96 gibi farklı oranlar gösterilmesine karşın tüm çalışmalarda karaciğer en sık tutulan organ olma özelliğini korumaktadır $(16,22)$.

$\mathrm{Bu}$ çalışmada radyolojik KE bulgusu olan hastalarda IHA pozitifliği kist lokalizasyonlarıyla karşılaştırılmıştır. Karaciğerde KE düşünülen hastalarda IHA pozitiflik oranı \%37,6 iken diğer organ lokalizasyonlarında bu oran \%25,5 olarak bulunmuştur. Literatürde karaciğer kist hidatik olgularında daha yüksek IHA pozitiflik oranları elde edildiğine dair çalışmalar bulunmaktadır (23). Bazı çalışmacıların karaciğer tutulumunda yüksek titrelere rastlamasının nedeni kistin lokalizasyonuna göre bağışıklık sisteminin verdiği antikor yanıtının değişmesi, buna bağlı olarak da serolojik testlerin duyarlılığının değişkenlik göstermesi olabilir (24). Bu bağlamda karaciğerde yerleşen kist hidatiğin daha güçlü immünolojik yanıta yol açtığı düşünülmektedir (25). Ancak çalı̧̧mamızda karaciğer ve diğer organ tutulumları arasındaki IHA pozitiflik oran farkı istatistiksel olarak anlamlı bulunmamıştır. Miman ve ark.'nın (21) $91 \mathrm{KE}$ tanılı hastada yaptığı değerlendirmede de kist lokalizasyonu ve IHA pozitifliği arasında anlamlı bir ilişki gösterilmemiştir.

\section{SONUÇ}

$\mathrm{Bu}$ çalışmada bölgemizde halen önemli bir sağlık problemi olan KE'nin ön tanısında kullanılan iki yöntemin karşılaştırılması amaçlanmıştır. Bu çalışmanın en önemli kısıtlılı̆̆ı verilerin retrospektif olarak taranmış olması, dolayısıyla hastaların uzun dönem takiplerinin yapılmamış olmasıdır.

Çalışmamız sonucunda; tanı yöntemi olarak sadece görüntüleme yöntemi kullanılmasının, yer kaplayan diğer lezyonlarla ayırıcı tanısında yetersiz kalabileceği, sadece serolojik testler kullanılmasının da kişisel immün yanıt farklılıkları ve çapraz reaksiyon gibi nedenlerden ötürü kısıtlllıkları olabileceği; bu nedenle iki tanı yönteminin birlikte kullanılmasının gerekli olduğu sonucuna varılmıştır.

\section{* Etik}

Etik Kurul Onayı: Bu çalışma için Necmettin Erbakan Üniversitesi Etik Kurulu'ndan izin alınmıştır (2019/98).

Hasta Onayı: Retrospektif çalışma olduğu için hastalardan tek tek onay alınmamıştır.

Hakem Değerlendirmesi: Editörler kurulu ve editörler kurulu dışında olan kişiler tarafından değerlendirilmiştir.

\section{* Yazarlık Katkıları}

Konsept: F.E.T., B.Y., C.K., M.S.İ, Dizayn: F.E.T., B.Y., C.K., M.S.İ., Veri Toplama veya İşleme: F.E.T., B.Y., C.K., M.S.İ., Analiz veya Yorumlama: F.E.T., B.Y., C.K., M.S.İ., Literatür Arama: F.E.T., B.Y., Yazan: F.E.T., B.Y.

Çıkar Çatışması: Yazarlar tarafından çıkar çatışması bildirilmemiştir.

Finansal Destek: Yazarlar tarafından finansal destek bildirilmemiştir.

\section{KAYNAKLAR}

1. Ertabaklar H, Dayanır Y, Ertuğ S. Aydın ilinin farklı bölgelerinde ultrason ve serolojik yöntemlerle kistik ekinokokkoz araştırılması ve eğitim çalışmaları. Turkiye Parazitol Derg 2012; 36: 142-6.
2. Akgün S, Sayiner HS, and Karslıgil T. Kistik Ekinokokoz'un serolojik tanısında indirekt hemaglütinasyon, Indirekt Floresan Antikor ve Enzim İmmuno Assay testlerinin etkinliğinin değerlendirilmesi. Çağdaş Tip Dergisi 2018; 8: 14-9.

3. Ertuğ S, Çalışkan SÖ, Malatyalı E, Ertabaklar H. Kistik Ekinokokkozis Tanısında Hızlı Tanı Testinin Uygulanabilirliğinin Araştırılması. Turkiye Parazitol Derg 2018; 42: 118-21.

4. Cetinkaya U, Hamamcı B, Kaya M, Gücüyetmez S, Kuk S, Yazar S, Sahin I. Kistik Ekinokokkozis Ön Tanılı Hastalarda Anti-Echinococcus granulosus Antikorlarının Araștırılması [Investigation of anti-Echinococcus granulosus antibodies in patients with suspected cystic echinococcosis]. Turkiye Parazitol Derg 2012; 36: 57-60.

5. Eckert J, Deplazes P. Biological, epidemiological, and clinical aspects of echinococcosis, a zoonosis of increasing concern. Clin Microbiol Rev 2004; 17: 107-35.

6. Aslan MH, Kurt A,Vural MK. Kistik Ekinokokkozis Ön Tanılı Hastaların İndirekt Hemaglütinasyon (İHA) Test Sonuçlarının Araştırılması Van Tıp Derg 2019; 26: 158-61.

7. Miman Ö, Saygı G-Temel Tıbbi Parazitoloji / İstanbul Tıp Kitabevi 2018; $\mathrm{p}: 241-248$

8. Uysal EB, Özdemir M, and Baykan M. Kistik ekinokokkozis tanısında ticari İndirekt Floresan Antikor (IFA), İndirekt Hemaglutinasyon (IHA) testleri ve laboratuvarımızda hazırladığımız IFA testinin karşılaştırılması. Turkiye Parazitol Derg 2009; 33: 195-8.

9. Yılmaz A, Karameşe M, Akkaş Ö, Uslu H. Kist Hidatik Şüpheli Hastaların Tanısında ELISA ve İmmunokromotografik Yöntemin Karşılaştırılması. Muğla Sıtkı Koçman Üniversitesi Tıp Dergisi 2016; 3: 13-6.

10. Garabedian GA, Matossian RM, Djanian AY. Serologic diagnosis of hydatid disease by indirect hemagglutination. J Med Liban 1957; 10: 275-82.

11. Gönlügür U, Gönlügür ET, and Akkurt İ. Kist hidatik tanısında serolojik testlerin değeri. Turkiye Klinikleri Archives of Lung 2004; 5: 158-61.

12. Ertabaklar H, Yıldız İ, Malatyalı E, Tileklioğlu E, Çalışkan SÖ, Ertuğ S. Aydın Adnan Menderes Üniversitesi Eğitim ve Araştırma Hastanesi Parazitoloji Laboratuvarı'na 2005-2017 Yllları Arasında Kistik Ekinokokkozis Şüphesiyle Başvuran Olguların Retrospektif Olarak Değerlendirilmesi. Turkiye Parazitol Derg 2019; 43: 118-22.

13. Tilkan OK, Uysal S, and Gökçe M. Hidatik Kist Hastalığı. Batı Karadeniz Tip Derg 2018; 2: 153-9.

14. Yazar S, Taylan ÖA, Hökelek M, Polat E, Yılmaz H, Özbilge H et al. Türkiye'de 2001-2005 Yılları Arasında Kistik Ekinokokkozis. Turkiye Parazitol Derg 2008; 32: 208-20.

15. Karadağ A, Yanık K, Ünal N, Odabaşı H, Hökelek M. Kistik Ekinokokkozis Şüphesi ile 2005-2011 Yılları Arasında Ondokuz Mayıs Üniversitesi Tıp Fakültesi Parazitoloji Laboratuvarına Gönderilen Örneklerin Değerlendirilmesi. Turkiye Parazitol Derg 2013; 37: 28-31.

16. Güreser AS, Özcan O, Özünel L, Boyacıoğlu Zİ, Taylan Özkan A. Çorum'da kistik ekinokokkoz ön tanısı ile başvuran hastaların radyolojik, biyokimyasal ve serolojik analizlerinin değerlendirilmesi [Evaluation of the radiological, biochemical and serological parameters of patients prediagnosed as cystic echinococcosis in Çorum, Turkey]. Mikrobiyol Bul 2015; 49: 231-9

17. Wuestenberg J, Gruener B, Oeztuerk S, Mason RA, Haenle MM, Graeter T, et al. Diagnostics in cystic echinococcosis: serology versus ultrasonography. Turk J Gastroenterol 2014; 25: 398-404.

18. Yılmaz GR, Babür C. Ekinokokkosis Tanısı. Türk Hij Den Biyol Derg 2007; 64: 35-44.

19. Kara M, Davarci M, and Dabanlioglu B. "Prevalence of cystic echinococcosis in humans in Erzincan Province." Annals of Medical Research 2020; 27 : 128-32.

20. Çitil BE, Tunçoğlu E, Erbil ÖF, Değirmenci M, Özenoğlu A, Sert H. Adıyaman'da Kistik Ekinokokkozis Ön Tanılı Hastaların İndirekt Hemaglütinasyon (IHA) Yöntemi ile Değerlendirilmesi. Van Tip Derg 2015; 22: 220-4. 
21. Miman Ö, Atambay M, Aydın NE, Daldal N. Kistik ekinokokkozis nedeniyle opere edilmiş 91 olguda klinik, morfolojik ve serolojik irdelemeler. Turkiye Parazitol Derg 2010; 34: 179-83.

22. Atambay M, Türkmen E, Karaman Ü, Söğütlü G, Aydın NE, Daldal N. "Unilokuler kistik ekinokokozis olgularında yapısal değişiklikler." Türkiye Ekopatoloji Dergisi 2005; 11: 71-4.

23. Kuru C, Baysal B. Uniloküler kistik ekinokokkozis 'in tanısında indirekt hemaglütinasyon yönteminin değeri. Turkiye Parazitol Derg 1999; 23 : 251-4.
24. Force L, Torres JM, Carrillo A, Buscá J. Evaluation of eight serologic altests in the diagnosis of human echinococcosis and follow-up. Clin Infect Dis 1992; 15: 473-80.

25. Moro P, Schantz PM. Echinococcosis: a review. Int J Infect Dis 2009; 13: 125-33. 